\title{
Leading the Academic Library in Strategic Engagement with Stakeholders: A Constructivist Grounded Theory
}

\section{Fiona Harland, Glenn Stewart, and Christine Bruce}

\begin{abstract}
The current diversity and disparate needs of stakeholders present significant challenges to academic libraries globally. The constructivist grounded theory presented in this paper recognizes the guiding role of the library director in responding to this problem and the need for different strategic mechanisms for engagement with various stakeholder groups. Key contributions of this work include establishing a strategic framework for engagement with stakeholders and tentative suggestions for various types of university libraries. The implications of this research include the need for outwardlooking library directors, an evidence-based approach to stakeholder engagement, and the encouragement of a customer-focused organizational culture among staff.
\end{abstract}

\section{Introduction}

Innovation in a service organization such as the academic library requires close engagement with customers. ${ }^{1}$ The increased technological and service expectations of faculty and students requires the academic library director to understand their needs and to intensify the pace of the library's adoption of technology and innovation in service. ${ }^{2}$ The library director defines the library's strategic direction and articulates its vision ${ }^{3}$ and therefore is responsible for ensuring that the library is engaged with its stakeholders in a way that satisfies their needs as well as accomplishing the mission of the library. Therefore, this paper asks, "how does the university library director ensure the library is engaging with its stakeholders?"

Engagement involves "practices, processes and actions that an organisation must perform to involve stakeholders in any organisational activity to secure their involvement and commitment, or reduce their indifference or hostility." ${ }^{4}$ A stakeholder is defined as any person with "an interest; rights (legal or moral); ownership; contribution in the form of knowledge or support" 5 toward the activity of the library. Therefore, the library director must ensure that the library's

Fiona Harland is a Researcher on the Faculty of Business, School of Management, at Queensland University of Technology; email: f.harland@connect.qut.edu.au. Glenn Stewart is an Adjunct Professor on the Science and Engineering Faculty, School of Information Systems, at Queensland University of Technology; email: g.stewart@ qut.edu.au. Christine Bruce is Dean of Graduate Research at James Cook University; email: christine.bruce@jcu. edu.au. The first author was a recipient of an Australian Postgraduate Award Scholarship and of a QUT Write-up Scholarship during this research. Ethics clearance was gained from the QUT Ethics Committee for the conduct of this research (QUT Ethics Approval Number 1400000814). @2019 Fiona Harland, Glenn Stewart, and Christine Bruce, Attribution-NonCommercial (http://creativecommons.org/licenses/by-nc/4.0/) CC BY-NC. 
strategy includes engaging students, faculty, and general staff in the library's activities and that stakeholders such as the university administration and donors are committed to the library as an important contributor to the university's outcomes.

The library director also plays a leadership role in creating and embedding organizational culture through personal values, beliefs, and actions. ${ }^{6}$ The library director's role includes engaging with the university's academic and wider community such as heads of faculty, university administrators, and library benefactors, ${ }^{7}$ instilling engagement culture in staff, and being a model for change to the wider university. ${ }^{8}$ This is important because the culture of the organization doing an activity can influence the attitude of stakeholders toward it. ${ }^{9}$

While there is much literature about the various forms of engagement as specified in the literature review that follows, there is no literature that provides a holistic engagement theory or model that examines all parts of the library's stakeholder engagement strategy. A holistic engagement theory and model is important because it provides an understanding of how library directors, senior library managers, and academic librarians can ensure the library is continuously engaging with stakeholders. Moreover, this paper specifies how the library engages with various stakeholder groups such as academic staff and researchers, university administrators, and external stakeholders such as donors and benefactors. This paper is also unique in providing a visual theoretical model that reminds the library director of the need for a consistent approach to engagement with stakeholders. Another distinctive aspect of this paper is the exploration of the experiences of library directors and the comparisons and contrasts between United States state system universities and four types of publicly funded Australian universities.

This paper reports a section of the findings of the research of Fiona Harland ${ }^{10}$ and Fiona Harland, Glenn Stewart, and Christine Bruce. ${ }^{11}$ The theory provides an understanding of how library directors can ensure their library is holistically and continuously engaging with stakeholders. ${ }^{12}$ The theory begins with the agency of the library director in recognizing the need for the library to know its stakeholders and their requirements and that the library's response is adequate. The library director, with senior library staff, then develops a holistic engagement framework that is mutually dependent upon an organizational culture that is actively and continuously engaging with the library's stakeholders. Various mechanisms then enable the library to engage with its stakeholder communities in ways that are appropriate to each group.

The results of this research may have significant impact upon the way different types of academic libraries engage with their stakeholders, producing a holistic strategic approach and encouraging a culture that will facilitate the discovery and introduction of new services. This research may also affect the way academic libraries recruit or train staff, bearing in mind the different challenges that face regional and metropolitan universities.

The paper proceeds with a literature review that establishes the need for an engagement theory and model. Following this is an explanation of constructivist grounded theory research method and the steps taken to achieve the theory. The findings are then presented, followed by a discussion of the results.

\section{Literature Review}

The concept of engagement with stakeholders is well understood in the library and information science (LIS) domain. The importance of the academic library's engagement with its 
stakeholders derives from the body of research of A. Parasuraman, who argued that customers will look elsewhere for their service needs to be met if service does not meet the minimum level of their zone of tolerance. ${ }^{13}$ However, the role of university library directors in ensuring their libraries are engaging with all stakeholders in a strategic way is less well understood.

The literature that discusses the individual ways in which academic libraries engage with their stakeholder groups is voluminous. For example, several studies describe the use of qualitative and quantitative research methods to investigate the requirements of stakeholders and the efficacy of the library's services. These include the recent works of Rachel Esson et al. ${ }^{14}$ and Ben Wynne et al. ${ }^{15}$ The studies of Kayo Denda, ${ }^{16}$ Kayo Denda and Jennifer Hunter, ${ }^{17}$ and Mark Robertson ${ }^{18}$ identify the contribution that academic libraries make toward student success and teaching and learning. According to Roisin Gwyer ${ }^{19}$ and L. Johnson et al., ${ }^{20}$ academic libraries are using their physical space in a variety of new ways as a means of engaging with stakeholders. Some studies (Zelda Chatten and Sarah Roughly, ${ }^{21}$ Geraldine Delaney and Jessica Bates, $^{22}$ and Laura Saunders ${ }^{23}$ ) provide evidence that academic libraries are also engaging with stakeholders through various kinds of social media.

Another way that academic libraries are engaging is by becoming partners in learning (Mathew Long and Roger Schonfeld, ${ }^{24}$ Yvonne Meulemans and Allison Carr ${ }^{25}$ ). The works of Jared Hoppenfeld and Elizabeth Malafii ${ }^{26}$ and Belinda Tiffen and Ashley England ${ }^{27}$ find that academic libraries are also collaborating with faculties in their research endeavors. This includes using the institutional repository as a publishing tool, ${ }^{28}$ measuring research impact, ${ }^{29}$ and disseminating the research capabilities of the university staff. Such engagement also involves collaborating with researchers to provide metadata about their research and providing storage for their datasets. ${ }^{30}$ The studies of Melissa Dennis, ${ }^{31}$ Saunders, $^{32}$ and Shapiro ${ }^{33}$ also explore the academic library's engagement with communities that are external to the university.

Fewer studies examine the role of university library directors in ensuring that their libraries are engaging with stakeholders. The ethnographic research of Maria Otero-Boisvert ${ }^{34}$ explores the role of the library director in gaining funding from the university administration. Robertson ${ }^{35}$ investigates the perceptions of provosts of Canadian research-intensive universities about their libraries. The grounded theory research by Linh Cuong Nguyen ${ }^{36}$ generated a holistic participatory library model for academic libraries. The participatory library model was based upon the perceptions of several levels of librarians and students. While related to this paper in producing a holistic approach to user participation or engagement, the paper presented by Nguyen $^{37}$ does not explore the actions of the library director in ensuring that the library is engaging with its stakeholders. Therefore, this paper specifically focuses upon the role of the library director in ensuring that all library staff are engaging with stakeholders; it is unique in examining the different engagement mechanisms used by different university library types.

\section{Research Method}

This study employed constructivist grounded theory to investigate the experiences of university library directors in ensuring that the library engages with stakeholders. Constructivist grounded theory was developed in the 1990s by Kathy Charmaz and is an interpretivist revision of the original formal or classic grounded theory of Barney Glaser and Anselm Strauss. ${ }^{38}$ This research method is necessary when current theories are inadequate for the phenomenon being examined ${ }^{39}$ and is suitable for answering what and how questions. ${ }^{40}$ Therefore, it is an appropriate method for the research problem investigated here. 
In general, grounded theory is characterized by several procedures relating to data collection and analysis. These include an inductive approach to the research; sampling that aims for theory development rather than a representative sample; simultaneous data collection and analysis while also constantly comparing data with data, and data with codes; memo writing that enables theory development; and a literature review that occurs after theory has been sufficiently developed. ${ }^{41}$

In a constructivist grounded theory, the developed theory is viewed as the result of the researcher and the participants' mutually constructed interpretation of multiple realities. ${ }^{42}$ The researcher checks the accuracy of the interpretation through active listening during the interview, during follow-up interviews, and in checking that the theory is resonating with participants. ${ }^{43}$ The substantive grounded theory is written as a tentative interpretation of the different responses of participants. A stance of "theoretical agnosticism" ${ }^{\prime 4}$ allowed the theory to emerge from analysis of the data.

The main criterion for inclusion of participants in this study was that they had significant experience as the library director (at least five years) or were leading academic libraries that are at the forefront of the industry in continually innovating new services, developing staff, and fulfilling student expectations. At the beginning of the study, five distinct library types were identified, and the recruitment of two participants from each of these contexts provided an opportunity for comparison between the different contexts, adding nuance and credibility to the theory. ${ }^{45}$

The range of publicly funded university types in the entire sample, as shown in table 1 , included the following: universities of technology from metropolitan areas in Australia; research universities from regional areas in Australia; regional universities in Australia; metropolitan elite universities in Australia; and state system universities in the United States. The Australian public funding system closely resembles that of the United States, ${ }^{46}$ but Australian universities' heavy reliance upon government funding has made them less competitive than their American counterparts. Moreover, in recent years, Australian governments have pressured them to imitate the mission and financing models of American universities ${ }^{47}$ These demands make a comparison with the strategies of American state system university libraries important for Australian library directors.

The research commenced after obtaining human research ethics approval, with initial sampling (December 2014 to June 2015) and theoretical sampling (October to November 2015). The first library directors were identified and recruited through convenience sampling, with later participants identified through snowball sampling from the recommendations of earlier interviewees. The interview protocol for the main study (see appendix) was devised during the pilot study phase by the lead researcher because the research team considered the pilot interview protocol was too structured and data forcing. ${ }^{48}$ The main study interview protocol began with an open-ended question, which was followed by more concept-based questions if the participant did not answer the first question fully. These questions were designed to elicit the library directors' experiences, rather than the interviewer's interests. ${ }^{49}$ Participants were sent a copy of the protocol to peruse prior to the interview and were free to answer the main question or some or all related interview questions during the interview, which took place either face to face or by Skype ${ }^{\mathrm{TM}}$.

Table 1 provides details of the participants and their level of participation in the study. The first participant was interviewed during the pilot phase of the study and was interviewed 
again later with the main study interview protocol (see appendix). We originally interviewed Library Director 10 (D10) as a regional university participant, but during analysis we deemed that this university should be classed as a research university. During the later theoretical sampling phase, one prior participant (D7) and two new participants (D11 and D12) were recruited to explore areas of the theory that required refinement. ${ }^{50}$ Library Director 12 (D12) was from a regional university and therefore rounded out the thin data for regional universities. While a sample of 12 participants and 14 interviews is small, a constructivist grounded theory sample size is determined by the quality of the data, the depth of data saturation, and whether the theory is substantial and makes sense to researchers and participants. ${ }^{51}$ Data collection ceased after 14 interviews because the participants produced high-quality data, allowing early saturation of the relevant themes. To protect the identities of participants and their universities, no further identifying data are provided in this table.

\begin{tabular}{|l|l|l|}
\hline \multicolumn{3}{|c|}{ Range of University Libraries in the Research Sample } \\
\hline \multicolumn{1}{|c|}{ Participant Code } & \multicolumn{1}{|c|}{ University Type } & \multicolumn{1}{c|}{ Location } \\
\hline $\begin{array}{l}\text { Library Director } 1 \text { (D1) } 2 \text { initial sampling } \\
\text { interviews }\end{array}$ & State system university & Metropolitan, United States \\
\hline Library Director 2 (D2) & University of Technology & Metropolitan, Australia \\
\hline Library Director 3 (D3) & Research university & Regional city, Australia \\
\hline Library Director 4 (D4) & Regional university & Regional, Australia \\
\hline Library Director 5 (D5) & Elite university & Metropolitan, Australia \\
\hline Library Director 6 (D6) & Elite university & Metropolitan, Australia \\
\hline $\begin{array}{l}\text { Library Director } 7 \text { (D7) Initial and theoretical } \\
\text { sampling interviews }\end{array}$ & Research university & Metropolitan/regional, Australia \\
\hline Library Director 8 (D8) & University of Technology & Metropolitan, Australia \\
\hline Library Director 9 (D9) & State system university & Metropolitan, United States \\
\hline Library Director 10 (D10) & Research university & Regional city, Australia \\
\hline $\begin{array}{l}\text { Library Director 11 (D11) Theoretical } \\
\text { sampling interview }\end{array}$ & Elite university & Metropolitan, Australia \\
\hline $\begin{array}{l}\text { Library Director 12 (D12) Theoretical } \\
\text { sampling interview }\end{array}$ & Regional university & Regional, Australia \\
\hline
\end{tabular}

It is important to note that the data collection and data comparison and analysis were simultaneous and constant activity, rather than distinct phases. The immediate transcription and initial coding of each interview by the lead researcher enabled the pursuit of new areas of inquiry with later participants. ${ }^{52}$ However, three distinct phases of analysis included initial, focused coding and theoretical coding.

Initial coding began by asking questions of the data, fracturing the data, and comparing it with other data in the same and previous interviews. ${ }^{53}$ The interview transcripts were coded into as many codes as possible. As coding progressed with each interview, previous codes were refined or relabeled. After all initial interviews were complete, the lead researcher analyzed the data using focused coding, which entailed isolating the codes with "greater analytic power." ${ }^{54} \mathrm{NVivo}^{\mathrm{TM}}$ software assisted the coding process, comparison of the codes 
and memo writing. Memo writing aided the analysis of each interview, where emerging patterns were noted.

Upon the completion of focused coding, it was clear that some areas of inquiry were not developed sufficiently. ${ }^{55}$ It appeared that the elite university library directors did not emphasize a team or collaborative culture, as other participants had, and that the data for regional university libraries was sparse. Therefore, we recruited an extra regional participant (D12) and an extra elite university library director (D11). To inquire more about the nature of library reinventions, we interviewed participants who had initiated major library restructures (D7, D11, and D12). Specific theoretical sampling questions were devised (see appendix). At the completion of this stage, the new codes were categorized into the same categories and focused codes, thus showing that the research had reached saturation, at which time sampling could cease.

The theoretical coding stage involved defining the focused codes and categories and arranging them into an integrated theory that specifies their relationships with each other. ${ }^{56}$ The categories are codes that are significant, allowing the researcher to raise the analysis from a descriptive to a conceptual level..$^{57}$ The sequence of the categories focused first upon the problem, then upon the actions or strategies, and finally, if possible, upon the consequences of those actions (mechanisms), as shown in the model (see figure 1). Finally, we interviewed four participants to check that the theory resonated with their experience, thus adding credibility to the substantive grounded theory. ${ }^{58}$

\section{The Findings}

The substantive grounded theory of how library directors ensure academic library engagement with stakeholders is presented as five categories or themes that explain what is occurring and why it is occurring. ${ }^{59}$ As shown in figure 1, the categories also represent the following abstract concepts: the library director's problem; the strategic response; the organizational culture required; and the mechanisms that deliver the strategy. We also present the multiple perspectives of participants and make comparisons between university types. These perspectives are presented in tables 2 through 6.

The term "engagement" incorporates concepts or phrases such as "liaison," "promotion," "promoting awareness," "building relationships," and "collaborating." Director 4 (D4) states that the consequence of non-engagement with stakeholders is this: "if you sit back and wait for them to ask, often it won't happen. They'll sit back and grumble about what they're not getting, but you'll be none the wiser." Library Director 8 (D8) stated that engagement is "an item on all of our management meeting agendas, and everybody knows it's a significant issue." Library Director 5 (D5) noted that English universities included engagement as a factor in their rankings; therefore, this model was copied at the elite university where D5 reports to the Vice Principal for Engagement.

Engaging with stakeholders has a dual purpose. It enables the library to find out the needs of stakeholders and how the library can meet those needs. It also allows the library to promote itself, its brand, and its services, thereby maintaining its relevance. Library Director 7 (D7) commented that "by staying engaged you are able to promote what you do and you're able to get feedback from those people." Director 4 remarked that, to maintain relevance, the library must "ensure that our stakeholders understand our role in the academic environment and what we do." 


\section{The Problem: Diversity of Stakeholders and Their Requirements}

The participants identified a major challenge for university libraries as the diversity of stakeholders and their requirements. The participants from some of the regional universities claimed the biggest challenges because they had more diverse student populations. These universities tended to the needs of many first-year students who were at risk of dropping out due to being first in family, low socioeconomic status, or low-ranking tertiary admission students.

On the other hand, the elite university libraries of D5 and D6 struggled with the problem of the entrenched attitude of academic staff toward changes in the library. Library Director 6 (D6) expressed frustration about the expectation to maintain print collections, while also building electronic collections. D5 mentioned the problems the university has had with academics making public protests (website protests, full-page advertisements in newspapers) about library changes. Library Director 11 (D11) expressed an awareness of this problem in other universities and therefore proceeded cautiously with an organizational restructure. Table 2 (below) illustrates how the participants from different university contexts perceived the challenges they faced in ensuring the library is engaging with stakeholders.

\begin{tabular}{|l|l|l|l|l|l|}
\hline \multicolumn{7}{|c|}{ TABLE 2} \\
\multicolumn{1}{|c|}{$\begin{array}{c}\text { Summary of } \\
\text { Codes }\end{array}$} & $\begin{array}{c}\text { State System } \\
\text { Universities } \\
\text { (United States) }\end{array}$ & $\begin{array}{c}\text { Technology } \\
\text { Universities } \\
\text { (Australia) }\end{array}$ & $\begin{array}{c}\text { Research } \\
\text { Universities } \\
\text { (Regional Australia) }\end{array}$ & $\begin{array}{c}\text { Regional } \\
\text { Universities } \\
\text { (Australia) }\end{array}$ & $\begin{array}{c}\text { Elite Universities } \\
\text { (Australia) }\end{array}$ \\
\hline $\begin{array}{l}\text { Coping with } \\
\text { Diversity of } \\
\text { Stakeholders }\end{array}$ & & $\begin{array}{l}\text { Stakeholder } \\
\text { diversity (D2, } \\
\text { D8) }\end{array}$ & $\begin{array}{l}\text { Student diversity } \\
\text { (D7) }\end{array}$ & $\begin{array}{l}\text { - Student } \\
\text { diversity } \\
\text { (D4) }\end{array}$ & $\begin{array}{l}\text { Stakeholder } \\
\text { diversity (D5, D6) }\end{array}$ \\
\hline $\begin{array}{l}\text { Stakeholder } \\
\text { Requirements }\end{array}$ & & & $\begin{array}{l}\text { - First-year students } \\
\text { (D7) }\end{array}$ & $\begin{array}{l}\text { - First-year } \\
\text { students } \\
\text { (D4) }\end{array}$ & $\begin{array}{l}\text { - Expectations of } \\
\text { academic staff } \\
\text { (D5, D6, D11) }\end{array}$ \\
\hline
\end{tabular}

\section{Strategy: Stakeholder Engagement Framework}

The library directors revealed various strategies to deal with the diversity of stakeholders, and several participants revealed that the Council of Australian University Librarians (CAUL) was preparing an overall engagement framework. According to D5, this was to add "process and thought to the way that we actually identify who our stakeholders are and develop strategies that point to each of those different stakeholders."

The development of a stakeholder engagement framework involved the following strategies: developing a "whole of organization" approach; recognizing different strategies for different stakeholders; and communicating with stakeholders in their own language. According to D6, a "whole of organization approach" involves all library staff levels in relationship building with stakeholders, because "It's not one person building a relationship with another person, or even one person developing a relationship with a group." D8 emphasized the importance of the library director's role in liaising with the Deans and Heads of Department and the library management role in networking with others throughout the university.

There are also different strategies for different stakeholders, and (as D6 stated) the same message about the library is scaffolded across different levels. The communication channels and 
terminology are also different for students and university administrators, for (as D3 asserted) the message must be communicated "in a manner and in a language which is meaningful to your stakeholders." Library Directors 1 and 9 (D1, D9) emphasized the importance of communicating with administrators in the language of the university, while students respond well to social media. Table 3 below provides a summary of the data pertaining to the development of an engagement framework.

\begin{tabular}{|c|c|c|c|c|c|}
\hline \multicolumn{6}{|c|}{$\begin{array}{c}\text { TABLE } 3 \\
\text { Summary of Data for Strategy: Stakeholder Engagement Framework }\end{array}$} \\
\hline $\begin{array}{l}\text { Focused } \\
\text { Codes }\end{array}$ & $\begin{array}{l}\text { State System } \\
\text { Universities } \\
\text { (United } \\
\text { States) }\end{array}$ & $\begin{array}{l}\text { Technology } \\
\text { Universities } \\
\text { (Australia) }\end{array}$ & $\begin{array}{l}\text { Research } \\
\text { Universities } \\
\text { (Regional } \\
\text { Australia) }\end{array}$ & $\begin{array}{l}\text { Regional } \\
\text { Universities } \\
\text { (Australia) }\end{array}$ & $\begin{array}{l}\text { Elite Universities } \\
\text { (Australia) }\end{array}$ \\
\hline $\begin{array}{l}\text { Different } \\
\text { Strategies } \\
\text { for Different } \\
\text { Stakeholders }\end{array}$ & & & & $\begin{array}{l}\text { - Different } \\
\text { strategies } \\
\text { for different } \\
\text { stakeholders } \\
\text { (D12) }\end{array}$ & $\begin{array}{l}\text { - Framework } \\
\text { developed by } \\
\text { national university } \\
\text { librarians network } \\
\text { (D5, D6) } \\
\text { - Different strategies } \\
\text { for different } \\
\text { stakeholders (D5, D6) }\end{array}$ \\
\hline $\begin{array}{l}\text { Whole } \\
\text { Organization } \\
\text { Approach }\end{array}$ & & $\begin{array}{l}\text { - Engagement at } \\
\text { all levels (D2, } \\
\text { D8) }\end{array}$ & & & $\begin{array}{l}\text { - Engagement at all } \\
\text { levels (D5, D6) }\end{array}$ \\
\hline $\begin{array}{l}\text { Using } \\
\text { Stakeholder } \\
\text { Language }\end{array}$ & $\begin{array}{l}\text { - Using the } \\
\text { language of } \\
\text { the university } \\
\text { (D1, D9) }\end{array}$ & $\begin{array}{l}\text { - Honest } \\
\text { communication } \\
\text { (D8) }\end{array}$ & $\begin{array}{l}\text { - Using } \\
\text { stakeholder } \\
\text { language (D3, } \\
\text { D10) }\end{array}$ & $\begin{array}{l}\text { - Don't } \\
\text { overpromise } \\
\text { on service } \\
\text { delivery (D4) }\end{array}$ & \\
\hline
\end{tabular}

\section{Organizational Culture: Encouraging an Engaged Culture}

Developing an engaged organizational culture is important because, as D7 stressed, "You can push as hard as you like to show how relevant you are, but if that's not being demonstrated by your workforce, then it's not going to go anywhere." According to participants, an engaged culture requires a customer focus and a team culture.

A customer focus is established by recruiting staff with a service orientation who are also active networkers. Staff who network will also collaborate with others on projects. The library directors regarded the role of liaison librarians as important in fostering collaboration between the library and other departments, and they believe that staff need to be adaptable and rapidly responsive to the requests and needs of customers. D8 stated that the library aims to "forge a reputation" as a "can-do culture."

The desired collaborative culture is established through a team culture. Team culture is built by decentralizing decision-making structures and empowering staff and teams to make decisions and solve problems themselves, without referring service problems to supervisors. This encourages more efficient customer service. The theme of loosening hierarchy and empowerment of staff was echoed by most participants; as D7 remarked: "we want people to lead no matter what level they are." However, D8 stated that: 
"In some university libraries there is a much more rigorous, hierarchical, and less democratic way of governing the library. We're not like that. It's a much more free, more open process, but within certain guidelines, nevertheless."

Working together toward a common vision, according to Library Director 12 (D12), is about "getting them all [staff] on board and feeling like they mattered." Several participants remarked that library staff produce better outcomes when working together rather than alone. The library directors also emphasize open communication with staff by talking to and consulting with staff and publishing meeting agendas and minutes. This occurred within either the highly sophisticated communications structure of D1 or a simpler team meeting culture. Directors 11 and 12 reported that sensitive library restructures required a longer period of consultation with staff.

Table 4 below provides a summary of the supporting data that the participants provided. All participants conveyed a strong interest in nurturing a customer-focused, collaborative, and promotional culture, although the elite universities spoke less about agility or flexibility. Similarly, while most participants spoke of the importance of a team culture, the participants from elite universities discussed teams less.

\begin{tabular}{|c|c|c|c|c|c|}
\hline \multicolumn{6}{|c|}{$\begin{array}{c}\text { TABLE } 4 \\
\text { Summary of Data for Organizational Culture: Encouraging an Engaged Culture }\end{array}$} \\
\hline Focused Codes & $\begin{array}{l}\text { State System } \\
\text { Universities } \\
\text { (United States) }\end{array}$ & $\begin{array}{l}\text { Technology } \\
\text { Universities } \\
\text { (Australia) }\end{array}$ & $\begin{array}{l}\text { Research } \\
\text { Universities } \\
\text { (Regional } \\
\text { Australia) }\end{array}$ & $\begin{array}{c}\text { Regional } \\
\text { Universities } \\
\text { (Australia) }\end{array}$ & $\begin{array}{c}\text { Elite } \\
\text { Universities } \\
\text { (Australia) }\end{array}$ \\
\hline $\begin{array}{l}\text { Customer- } \\
\text { focused Service }\end{array}$ & $\begin{array}{l}\text { - Customer- } \\
\text { focused service } \\
\text { (D1) }\end{array}$ & $\begin{array}{l}\text { - Customer- } \\
\text { focused } \\
\text { service (D2, } \\
\text { D8) }\end{array}$ & $\begin{array}{l}\text { - Customer- } \\
\text { focused service } \\
\text { (D3, D7, D10) }\end{array}$ & $\begin{array}{l}\text { - Customer- } \\
\text { focused service } \\
\text { (D4, D12) }\end{array}$ & $\begin{array}{l}\text { - Customer- } \\
\text { focused service } \\
\text { (D5, D11) }\end{array}$ \\
\hline $\begin{array}{l}\text { Fostering } \\
\text { Collaboration } \\
\text { with } \\
\text { Stakeholders }\end{array}$ & $\begin{array}{l}\text { - Staff can } \\
\text { naturally } \\
\text { collaborate (D1) } \\
\text { - Partnering } \\
\text { through "library } \\
\text { as lab" (D1) }\end{array}$ & $\begin{array}{l}\text { - Ensuring } \\
\text { staff are } \\
\text { networking/ } \\
\text { partnering } \\
\text { with } \\
\text { stakeholders } \\
\text { (D2, D8) }\end{array}$ & $\begin{array}{l}\text { - Recruiting staff } \\
\text { with outward / } \\
\text { collaborative } \\
\text { focus (D7) }\end{array}$ & $\begin{array}{l}\text { - Restructuring } \\
\text { to ensure } \\
\text { collaboration } \\
\text { and } \\
\text { engagement } \\
\text { (D12) }\end{array}$ & $\begin{array}{l}\text { - Partnering } \\
\text { librarians/ } \\
\text { library with } \\
\text { faculties (D5, } \\
\text { D6) }\end{array}$ \\
\hline $\begin{array}{l}\text { Responsiveness } \\
\text { to Stakeholder } \\
\text { Requirements }\end{array}$ & $\begin{array}{l}\text { - Responsive, } \\
\text { flexible, agile } \\
\text { (D1) }\end{array}$ & $\begin{array}{l}\text { - Responsive, } \\
\text { flexible, agile } \\
\text { (D2, D8) }\end{array}$ & $\begin{array}{l}\text { - Responsive, } \\
\text { flexible, agile } \\
\text { (D10) }\end{array}$ & $\begin{array}{l}\text { - Responsive, } \\
\text { nimble, flexible } \\
\text { (D4) }\end{array}$ & \\
\hline $\begin{array}{l}\text { Promoting } \\
\text { the Library's } \\
\text { Services }\end{array}$ & $\begin{array}{l}\text { - Presenting, } \\
\text { defending, } \\
\text { communicating, } \\
\text { persuading } \\
\text { university } \\
\text { leaders (D1) }\end{array}$ & $\begin{array}{l}\text { - Promoting the } \\
\text { library (D2) } \\
\text { - Forging a } \\
\text { reputation } \\
\text { (D8) } \\
\text { - Creating visual } \\
\text { identity (D8) }\end{array}$ & $\begin{array}{l}\text { - Promoting the } \\
\text { library (D3, D7, } \\
\text { D10) }\end{array}$ & - Engaging (D12) & $\begin{array}{l}\text { - Growth area of } \\
\text { engagement } \\
\text { and } \\
\text { fundraising } \\
\text { (D5, D11) }\end{array}$ \\
\hline
\end{tabular}


TABLE 4

Summary of Data for Organizational Culture: Encouraging an Engaged Culture

\begin{tabular}{|c|c|c|c|c|c|}
\hline Focused Codes & $\begin{array}{c}\text { State System } \\
\text { Universities } \\
\text { (United States) }\end{array}$ & $\begin{array}{l}\text { Technology } \\
\text { Universities } \\
\text { (Australia) }\end{array}$ & $\begin{array}{c}\text { Research } \\
\text { Universities } \\
\text { (Regional } \\
\text { Australia) } \\
\end{array}$ & $\begin{array}{c}\text { Regional } \\
\text { Universities } \\
\text { (Australia) }\end{array}$ & $\begin{array}{c}\text { Elite } \\
\text { Universities } \\
\text { (Australia) }\end{array}$ \\
\hline $\begin{array}{l}\text { Teams with } \\
\text { Egalitarian } \\
\text { Approach to } \\
\text { Reporting } \\
\text { Structures }\end{array}$ & $\begin{array}{l}\text { - Wary of } \\
\text { hierarchical } \\
\text { language (D1) }\end{array}$ & $\begin{array}{l}\text { - Less rigid or } \\
\text { hierarchical } \\
\text { (D8) }\end{array}$ & $\begin{array}{l}\text { - } \text { All staff } \\
\text { members on } \\
\text { project teams } \\
\text { (D10) } \\
\text { - All staff may } \\
\text { need to lead } \\
\text { projects (D7) }\end{array}$ & $\begin{array}{l}\text { - All staff } \\
\text { involved in } \\
\text { environmental } \\
\text { scan (D12) }\end{array}$ & \\
\hline $\begin{array}{l}\text { Communicate } \\
\text { Openly with } \\
\text { Staff }\end{array}$ & $\begin{array}{l}\text { - } \text { Publishing } \\
\text { agendas and } \\
\text { minutes on } \\
\text { internet (D1) } \\
\text { - Communication } \\
\text { systems design } \\
\text { (D1) } \\
\text { - Team meeting } \\
\text { culture (D1, D9) }\end{array}$ & $\begin{array}{l}\text { - Informing } \\
\text { staff about } \\
\text { developments } \\
\text { in university } \\
\text { and sector } \\
\text { (D8) }\end{array}$ & $\begin{array}{l}\text { - Library goals } \\
\text { published on } \\
\text { website (D10) } \\
\text { - Collegiate } \\
\text { sharing of } \\
\text { information } \\
\text { during } \\
\text { restructure (D7) }\end{array}$ & $\begin{array}{l}\text { - Open 2-way } \\
\text { communication } \\
\text { with Director } \\
\text { and Vice- } \\
\text { Chancellor (D4) } \\
\text { - Lengthy } \\
\text { consultation } \\
\text { and } \\
\text { communication } \\
\text { with staff during } \\
\text { restructure } \\
\text { (D12) }\end{array}$ & $\begin{array}{l}\text { - Lengthy } \\
\text { consultation } \\
\text { and } \\
\text { communication } \\
\text { with staff/trade } \\
\text { unions during } \\
\text { restructure } \\
\text { (D11) }\end{array}$ \\
\hline $\begin{array}{l}\text { Encouraging } \\
\text { Collaboration } \\
\text { among Staff }\end{array}$ & $\begin{array}{l}\text { - Collaborative } \\
\text { staff culture (D1 } \\
\text { - Staff naturally } \\
\text { collaborate (D1) }\end{array}$ & & $\begin{array}{l}\text { - Joint decision } \\
\text { making (D7) } \\
\text { - Encouraging } \\
\text { communication } \\
\text { of ideas (D7) }\end{array}$ & \begin{tabular}{|l} 
- Staff \\
encouraged to \\
communicate \\
ideas (D12)
\end{tabular} & \\
\hline $\begin{array}{l}\text { Working } \\
\text { toward a } \\
\text { Common } \\
\text { Vision }\end{array}$ & \begin{tabular}{|l} 
- Library staff \\
working \\
together \\
to produce \\
outcomes (D1, \\
D9) \\
\end{tabular} & $\begin{array}{l}\text { - Library staff } \\
\text { working } \\
\text { together } \\
\text { to produce } \\
\text { better } \\
\text { outcomes (D8) }\end{array}$ & $\begin{array}{l}\text { - Library staff } \\
\text { working } \\
\text { together to } \\
\text { produce better } \\
\text { outcomes (D7 }\end{array}$ & $\begin{array}{l}\text { - Ensuring staff } \\
\text { understand the } \\
\text { vision of the } \\
\text { future library } \\
\text { (D12) }\end{array}$ & \\
\hline
\end{tabular}

\section{Mechanisms: Engaging Internally within the University}

All participants discussed the mechanisms that delivered their strategies for engaging with their university stakeholders. These included formal mechanisms such as advisory boards and formal university reviews and informal mechanisms with the various stakeholders. Engagement with the highest administrative levels of the university was difficult for the library directors, as they are positioned lower in the university structure, but several participants mentioned the opportunity the institutional repository provides for engagement with the university executive. While D5 had a specific role in reporting to the Vice Principal, Engagement, the reporting structure of various library directors suggested that direct engagement with senior executive was rare, and only D2 had direct contact with the Vice Chancellor through "strategic walk arounds." 
Collaboration with departments and faculties is achieved informally through networking or through formal partnerships. Networking was important to many library directors, with D8 emphasizing the power of networks and the need to develop a reputation as a contributor to strategic networks. Such collaborations included partnering with various university departments on career services, IT, fundraising and engagement, marketing and communication, and financial services.

All participants regarded liaison with academic staff as crucial for providing a valueadded service, helping to avert academic staff resistance to change, and enabling collaboration on projects that promoted the work of academics while promoting the library. The Australian participants talked at length of the need for better support for researchers because of the recent changes to government funding policy. In response, many of the Australian participants had strengthened their research support teams. Finally, university libraries are involved in engaging and retaining students by gathering quantitative and qualitative feedback that helped them to understand student needs.

Table 5 below provides a summary of the formal and informal mechanisms that the library directors used for engaging with their diverse university stakeholders. As the table shows, D5 was most concerned about engagement, contributing the most data at the time of the interview. The directors of the two regional university libraries also expressed their focus on engaging with their stakeholders, with the smaller regional library of D4 struggling in servicing a smaller cohort of researchers. Library Director 12 (D12) used engagement strategies with staff and students to gain evidence for the library's restructure.

\begin{tabular}{|c|c|c|c|c|c|}
\hline \multicolumn{6}{|c|}{$\begin{array}{c}\text { TABLE } 5 \\
\text { Summary of Data for Mechanisms: Engaging Internally within the University }\end{array}$} \\
\hline Focused Codes & $\begin{array}{c}\text { State System } \\
\text { Universities } \\
\text { (United } \\
\text { States) }\end{array}$ & $\begin{array}{l}\text { Technology } \\
\text { Universities } \\
\text { (Australia) }\end{array}$ & $\begin{array}{l}\text { Research } \\
\text { Universities } \\
\text { (Regional } \\
\text { Australia) }\end{array}$ & $\begin{array}{l}\text { Regional } \\
\text { Universities } \\
\text { (Australia) }\end{array}$ & $\begin{array}{l}\text { Elite Universities } \\
\text { (Australia) }\end{array}$ \\
\hline $\begin{array}{l}\text { Formal } \\
\text { Mechanisms }\end{array}$ & $\begin{array}{l}\text { - Library board } \\
\text { (D9) }\end{array}$ & $\begin{array}{l}\text { - Formal reviews } \\
\text { (D2) }\end{array}$ & $\begin{array}{l}\text { - Library board } \\
\text { (D7) }\end{array}$ & $\begin{array}{l}\text { - Formal reviews } \\
\text { (D4) }\end{array}$ & $\begin{array}{l}\text { - Library board } \\
\text { (D11) } \\
\text { - Formal reviews } \\
\text { (D6, D11) }\end{array}$ \\
\hline $\begin{array}{l}\text { Highest } \\
\text { Administrative } \\
\text { Levels }\end{array}$ & $\begin{array}{l}\text { - Senior } \\
\text { administrators } \\
\text { (D1) }\end{array}$ & $\begin{array}{l}\text { - Senior } \\
\text { executive (D8) } \\
\text { - Vice Chancellor } \\
\text { (D2) } \\
\text { - Deputy Vice } \\
\text { Chancellor (D2) } \\
\text { - Deans and } \\
\text { department } \\
\text { heads (D8) }\end{array}$ & $\begin{array}{l}\text { - Vice and } \\
\text { Deputy Vice } \\
\text { Chancellor } \\
\text { (D10) }\end{array}$ & $\begin{array}{l}\text { - Director of } \\
\text { Information } \\
\text { (D4) } \\
\text { - Importance of } \\
\text { open two-way } \\
\text { communication } \\
\text { (D4) }\end{array}$ & $\begin{array}{l}\text { - Vice Principal } \\
\text { (D5) } \\
\text { - Deans and } \\
\text { department } \\
\text { heads (D5, D6) } \\
\text { - Vice Chancellor's } \\
\text { retreat (D5) } \\
\text { - Academic Board } \\
\text { (D5, D6) }\end{array}$ \\
\hline $\begin{array}{l}\text { Departments } \\
\text { and Faculties: } \\
\text { Informal }\end{array}$ & $\begin{array}{l}\text { - Library as lab } \\
\text { (D1) } \\
\text { - Spending } \\
\text { time with } \\
\text { faculty (D9) }\end{array}$ & $\begin{array}{l}\text { - Strategic } \\
\text { networking (D8) }\end{array}$ & $\begin{array}{l}\text { - Informal } \\
\text { meetings with } \\
\text { colleagues } \\
\text { (D3) }\end{array}$ & $\begin{array}{l}\text { - Frontline client } \\
\text { services (D4) }\end{array}$ & \\
\hline
\end{tabular}


TABLE 5

Summary of Data for Mechanisms: Engaging Internally within the University

\begin{tabular}{|c|c|c|c|c|c|}
\hline Focused Codes & $\begin{array}{c}\text { State System } \\
\text { Universities } \\
\text { (United } \\
\text { States) } \\
\end{array}$ & $\begin{array}{l}\text { Technology } \\
\text { Universities } \\
\text { (Australia) }\end{array}$ & $\begin{array}{c}\text { Research } \\
\text { Universities } \\
\text { (Regional } \\
\text { Australia) } \\
\end{array}$ & $\begin{array}{c}\text { Regional } \\
\text { Universities } \\
\text { (Australia) }\end{array}$ & $\begin{array}{c}\text { Elite Universities } \\
\text { (Australia) }\end{array}$ \\
\hline $\begin{array}{l}\text { Formal } \\
\text { Partnerships }\end{array}$ & & $\begin{array}{l}\text { - Divisional } \\
\text { or branch } \\
\text { colleagues (D2) }\end{array}$ & $\begin{array}{l}\text { - Divisional } \\
\text { or branch } \\
\text { colleagues } \\
\text { (D7) }\end{array}$ & $\begin{array}{l}\text { - Divisional } \\
\text { or branch } \\
\text { colleagues (D4) }\end{array}$ & $\begin{array}{l}- \text { Other } \\
\text { administrative } \\
\text { areas (D6) }\end{array}$ \\
\hline Project Teams & & $\begin{array}{l}\text { - Cross-university } \\
\text { project teams } \\
\text { (D8) }\end{array}$ & $\begin{array}{l}\text { - Cross- } \\
\text { university } \\
\text { project teams } \\
\text { (D3, D10) } \\
\end{array}$ & $\begin{array}{l}\text { - Cross-university } \\
\text { project teams } \\
\text { (D4) }\end{array}$ & \\
\hline $\begin{array}{l}\text { University } \\
\text { Committees }\end{array}$ & $\begin{array}{l}\text { - Committees } \\
\text { (D1) }\end{array}$ & \begin{tabular}{|l} 
- Committees \\
(D2, D8)
\end{tabular} & $\begin{array}{l}\text { - } \begin{array}{l}\text { Committees } \\
(\mathrm{D} 3, \mathrm{D} 7)\end{array} \\
\end{array}$ & $\begin{array}{l}- \text { Committees } \\
\text { (D4) }\end{array}$ & - Committees (D6) \\
\hline IT Department & & - IT (D2) & - IT (D3, D10) & & \\
\hline $\begin{array}{l}\text { Learning and } \\
\text { Teaching }\end{array}$ & \begin{tabular}{|l}
- Learning and \\
teaching (D1)
\end{tabular} & \begin{tabular}{|r}
- Learning and \\
teaching (D2) \\
\end{tabular} & $\begin{array}{r}\text { - Learning and } \\
\text { teaching (D7) } \\
\end{array}$ & & $\begin{array}{r}- \text { Learning and } \\
\text { teaching (D6) } \\
\end{array}$ \\
\hline Various & & $\begin{array}{l}\text { - Career services } \\
\text { (D8) } \\
\text { - Design thinking } \\
\text { workshops (D8) } \\
\text { - English } \\
\text { language } \\
\text { assistance (D8) }\end{array}$ & $\begin{array}{l}\text { - Fundraising } \\
\text { and } \\
\text { engagement } \\
\text { (D3) } \\
\text { - Research } \\
\text { services (D10) }\end{array}$ & & $\begin{array}{l}\text { - Marketing and } \\
\text { communications } \\
\text { (D5) } \\
\text { - Student services } \\
\text { (D5) } \\
\text { - Financial } \\
\text { services (D6) }\end{array}$ \\
\hline $\begin{array}{l}\text { Liaison Work } \\
\text { with Academic } \\
\text { Staff }\end{array}$ & $\begin{array}{l}\text { - Spending } \\
\text { time with } \\
\text { faculty (D9) }\end{array}$ & $\begin{array}{l}\text { - Liaison } \\
\text { librarians (D2, } \\
\text { D8) }\end{array}$ & $\begin{array}{l}\text { - Liaison } \\
\text { librarians (D3, } \\
\text { D10) }\end{array}$ & $\begin{array}{l}\text { - Liaison } \\
\text { librarians (D4) }\end{array}$ & $\begin{array}{l}\text { - Liaison librarians } \\
\text { (D6, D11) } \\
\text { - Attending } \\
\text { faculty meetings } \\
\text { (D5) }\end{array}$ \\
\hline $\begin{array}{l}\text { Collaboration } \\
\text { on Projects }\end{array}$ & $\begin{array}{l}\text { - Library as lab } \\
\text { (D1) }\end{array}$ & $\begin{array}{l}\text { - } \text { Research } \\
\text { collaboration } \\
\text { for curated } \\
\text { exhibitions (D8) } \\
\text { - Testing } \\
\text { electronic } \\
\text { research } \\
\text { notebooks (D2) } \\
\end{array}$ & $\begin{array}{l}\text { - Research } \\
\text { collaboration } \\
\text { for curated } \\
\text { exhibitions } \\
\text { (D10) } \\
\text { - Testing new } \\
\text { systems and } \\
\text { products (D7) } \\
\end{array}$ & $\begin{array}{l}\text { - Including } \\
\text { academics in } \\
\text { focus groups } \\
\text { (D12) }\end{array}$ & - MOOCS (D5) \\
\hline $\begin{array}{l}\text { Supporting } \\
\text { Researchers: } \\
\text { Expanding } \\
\text { Research } \\
\text { Support } \\
\text { Teams }\end{array}$ & $\begin{array}{l}\text { - Library as lab } \\
\text { (D1) } \\
\text { - Mutually } \\
\text { beneficial (D1) }\end{array}$ & $\begin{array}{l}\text { - Expanding } \\
\text { research } \\
\text { support team } \\
\text { (D2) }\end{array}$ & $\begin{array}{l}\text { - Expanding } \\
\text { research } \\
\text { support team } \\
\text { (D10) } \\
\text { - Outreach to } \\
\text { researchers } \\
\text { (D3, D7) }\end{array}$ & & $\begin{array}{l}\text { - Academic board } \\
\text { (D5) }\end{array}$ \\
\hline
\end{tabular}


TABLE 5

Summary of Data for Mechanisms: Engaging Internally within the University

\begin{tabular}{|c|c|c|c|c|c|}
\hline Focused Codes & $\begin{array}{c}\text { State System } \\
\text { Universities } \\
\text { (United } \\
\text { States) } \\
\end{array}$ & $\begin{array}{l}\text { Technology } \\
\text { Universities } \\
\text { (Australia) }\end{array}$ & $\begin{array}{c}\text { Research } \\
\text { Universities } \\
\text { (Regional } \\
\text { Australia) } \\
\end{array}$ & $\begin{array}{c}\text { Regional } \\
\text { Universities } \\
\text { (Australia) }\end{array}$ & $\begin{array}{c}\text { Elite Universities } \\
\text { (Australia) }\end{array}$ \\
\hline $\begin{array}{l}\text { Engaging and } \\
\text { Retaining } \\
\text { Students: } \\
\text { Knowing } \\
\text { Student Needs }\end{array}$ & $\begin{array}{l}\text { - Knowing } \\
\text { student needs } \\
\text { (D9) }\end{array}$ & $\begin{array}{l}\text { - Knowing } \\
\text { student needs } \\
\text { (D2, D8) } \\
\text { - Understanding } \\
\text { student culture } \\
\text { (D8) }\end{array}$ & \begin{tabular}{|l|} 
- Knowing \\
student needs \\
$(D 3, D 7)$
\end{tabular} & $\begin{array}{l}\text { - Knowing } \\
\text { student needs } \\
\text { (D4) }\end{array}$ & $\begin{array}{l}\text { - Knowing } \\
\text { student needs } \\
\text { (D5) }\end{array}$ \\
\hline $\begin{array}{l}\text { Gaining } \\
\text { Quantitative } \\
\text { Feedback }\end{array}$ & $\begin{array}{l}\text { - Survey } \\
\text { methods (D9) }\end{array}$ & $\begin{array}{l}\text { - Survey methods } \\
\text { (D2, D8) } \\
\text { - Statistics (D2) }\end{array}$ & $\begin{array}{l}\text { - Survey } \\
\text { methods (D3, } \\
\text { D7) } \\
\text { - Statistics (D3, } \\
\text { D10) }\end{array}$ & $\begin{array}{l}\text { - Survey } \\
\text { methods (D12) }\end{array}$ & $\begin{array}{l}\text { - Survey methods } \\
\text { (D5, D6) } \\
\text { - Statistics (D6) }\end{array}$ \\
\hline $\begin{array}{l}\text { Gaining } \\
\text { Qualitative } \\
\text { Feedback: } \\
\text { Formal } \\
\text { Methods }\end{array}$ & $\begin{array}{l}\text { - Participatory } \\
\text { design (D1) } \\
\text { - Meeting } \\
\text { with student } \\
\text { government } \\
\text { (D9) }\end{array}$ & & $\begin{array}{c}\text { - Focus groups } \\
(\mathrm{D} 3, \mathrm{D} 7)\end{array}$ & $\begin{array}{r}\text { - Participatory } \\
\text { design (D12) }\end{array}$ & $\begin{array}{l}\text { - Focus groups } \\
\text { (D5) }\end{array}$ \\
\hline $\begin{array}{l}\text { Gaining } \\
\text { Qualitative } \\
\text { Feedback: } \\
\text { Informal } \\
\text { Methods }\end{array}$ & $\begin{array}{l}\text { - Daily student } \\
\text { engagements } \\
\text { (D9) } \\
\text { - Observation } \\
\text { (D1) }\end{array}$ & $\begin{array}{l}\text { - Online } \\
\text { engagement } \\
\text { (D8) } \\
\text { - Observation } \\
\text { (D8) } \\
\text { - Student } \\
\text { internships (D8) } \\
\text { - Employing } \\
\text { students (D8) }\end{array}$ & $\begin{array}{l}\text { - Daily student } \\
\text { engagements } \\
\text { (D10) }\end{array}$ & $\begin{array}{l}\text { - Daily student } \\
\text { engagements } \\
\text { (D4) }\end{array}$ & $\begin{array}{l}\text { - Online } \\
\text { engagement } \\
\text { (D5) } \\
\text { - Student curators } \\
\text { (D5) } \\
\text { - Employing } \\
\text { students (D5) }\end{array}$ \\
\hline $\begin{array}{l}\text { Responding to } \\
\text { Feedback }\end{array}$ & $\begin{array}{l}\text { - Responding } \\
\text { to feedback } \\
\text { (D9) }\end{array}$ & $\begin{array}{l}\text { - Responding to } \\
\text { feedback (D2, } \\
\text { D8) } \\
\text { - Reporting back } \\
\text { to students (D2) }\end{array}$ & $\begin{array}{l}\text { - Responding } \\
\text { to feedback } \\
\text { (D7) }\end{array}$ & $\begin{array}{l}\text { - Responding to } \\
\text { feedback (D4) } \\
\text { - Reporting back } \\
\text { to students (D4) }\end{array}$ & $\begin{array}{l}\text { - Responding to } \\
\text { feedback (D5) } \\
\text { - Reporting back } \\
\text { to students (D5) }\end{array}$ \\
\hline $\begin{array}{l}\text { Promoting } \\
\text { the Library to } \\
\text { Students }\end{array}$ & & $\begin{array}{l}\text { - Posters (D2) } \\
\text { - Social media } \\
\text { (D8) }\end{array}$ & $\begin{array}{l}\text { - Social media } \\
\text { (D3) }\end{array}$ & & $\begin{array}{l}\text { - Posters (D5) } \\
\text { - Social media } \\
\text { (D5) } \\
\text { - Library events } \\
\text { (D5) }\end{array}$ \\
\hline
\end{tabular}




\section{Mechanisms: Engaging with External Stakeholders}

External stakeholders were also important to many participants. Engagement with external stakeholders included community engagement using library spaces and communications media. The elite library of D5 had the resources to promote the library through its art gallery spaces, university and newspaper publications, and art and collection catalogue publications. Library Director 3 (D3) of a regional research university reported using the local newspapers and electronic media to publicize their unique collections.

Donors were another important stakeholder. For D3, the liaison librarian had an important role in acquiring collections of specialist research material. The elite university libraries could raise funds to approach benefactors of money or of special collections (D5 and D11). External organizations such as the Australian National Data Service (ANDS) and communities of practice were also nominated as stakeholders (D2, D10).

The participants also emphasized the importance of the global and local library sector for sharing ideas and collaboration on projects. The Australian library directors referred frequently to CAUL (D2, 3, 4, 5, 6, 7, 10) and state-based organizations (D4). US Library Director 1 noted the importance of international links, while US Director 9 commented on the importance of liaising with other libraries such as public libraries. Finally, the university libraries engaged with potential students by running programs for local schools and by having relationships with various feeder institutions.

Table 6 below provides a summary and comparison of the mechanisms that the university libraries used in engaging with external stakeholders.

\begin{tabular}{|c|c|c|c|c|c|}
\hline \multicolumn{6}{|c|}{$\begin{array}{c}\text { TABLE } 6 \\
\text { Summary of Data for Mechanisms: Engaging with External Stakeholders }\end{array}$} \\
\hline $\begin{array}{l}\text { Focused } \\
\text { Codes }\end{array}$ & $\begin{array}{c}\text { State System } \\
\text { Universities } \\
\text { (United States) }\end{array}$ & $\begin{array}{l}\text { Technology } \\
\text { Universities } \\
\text { (Australia) }\end{array}$ & $\begin{array}{l}\text { Research } \\
\text { Universities } \\
\text { (Regional } \\
\text { Australia) }\end{array}$ & $\begin{array}{c}\text { Regional } \\
\text { Universities } \\
\text { (Australia) }\end{array}$ & $\begin{array}{l}\text { Elite Universities } \\
\text { (Australia) }\end{array}$ \\
\hline Community & & & $\begin{array}{l}\text { - Social media } \\
\text { (D3) } \\
\text { - Local media } \\
\text { outlets (D3) }\end{array}$ & & $\begin{array}{l}\text { - Social media (D5) } \\
\text { - Publications for } \\
\text { exhibitions (D5) } \\
\text { - University } \\
\text { newspaper } \\
\text { promotions (D5) }\end{array}$ \\
\hline Donors & & & $\begin{array}{l}\text { - Special } \\
\text { collections } \\
\text { librarian liaison } \\
\text { with donors } \\
\text { (D3) }\end{array}$ & & $\begin{array}{l}\text { - Soliciting } \\
\text { monetary } \\
\text { donations by } \\
\text { fundraising/ } \\
\text { advancement } \\
\text { manager (D5, } \\
\text { D11) }\end{array}$ \\
\hline $\begin{array}{l}\text { External } \\
\text { Organizations }\end{array}$ & & $\begin{array}{l}\text { - Australian } \\
\text { National Data } \\
\text { Service (D2) }\end{array}$ & $\begin{array}{l}\text { - Australian } \\
\text { National Data } \\
\text { Service (D10) } \\
\text { - Communities } \\
\text { of practice } \\
\text { (D10) }\end{array}$ & & \\
\hline
\end{tabular}




\begin{tabular}{|c|c|c|c|c|c|}
\hline \multicolumn{6}{|c|}{$\begin{array}{c}\text { TABLE } 6 \\
\text { Summary of Data for Mechanisms: Engaging with External Stakeholders }\end{array}$} \\
\hline $\begin{array}{l}\text { Focused } \\
\text { Codes }\end{array}$ & \begin{tabular}{|c|} 
State System \\
Universities \\
(United States)
\end{tabular} & $\begin{array}{l}\text { Technology } \\
\text { Universities } \\
\text { (Australia) }\end{array}$ & $\begin{array}{c}\text { Research } \\
\text { Universities } \\
\text { (Regional } \\
\text { Australia) }\end{array}$ & $\begin{array}{c}\text { Regional } \\
\text { Universities } \\
\text { (Australia) }\end{array}$ & $\begin{array}{l}\text { Elite Universities } \\
\text { (Australia) }\end{array}$ \\
\hline $\begin{array}{l}\text { Library } \\
\text { Sector }\end{array}$ & $\begin{array}{l}\text { - Other libraries } \\
\text { (D1, D9) } \\
\text { - Research } \\
\text { collaboration } \\
\text { (D1) } \\
\text { - Other } \\
\text { universities (D1) }\end{array}$ & $\begin{array}{l}\text { - Networks of } \\
\text { university } \\
\text { librarians } \\
\text { (D2) } \\
\text { - Research } \\
\text { collaboration } \\
\text { (D2) }\end{array}$ & $\begin{array}{l}\text { - Networks of } \\
\text { university } \\
\text { librarians (D3, } \\
\text { D7, D10) }\end{array}$ & $\begin{array}{l}\text { - Networks of } \\
\text { university } \\
\text { librarians } \\
\text { (D4) }\end{array}$ & $\begin{array}{l}\text { - Networks of } \\
\text { university } \\
\text { librarians (D5, } \\
\text { D6) }\end{array}$ \\
\hline $\begin{array}{l}\text { Schools } \\
\text { and Feeder } \\
\text { Institutions }\end{array}$ & & $\begin{array}{l}\text { - Schools (D2) } \\
\text { - Feeder } \\
\text { institutions } \\
\text { (D8) }\end{array}$ & $\begin{array}{l}\text { - Schools (D3) } \\
\text { - Colleges of } \\
\text { technical } \\
\text { and further } \\
\text { education (D7) }\end{array}$ & $\begin{array}{l}\text { - Schools (D4) } \\
\text { - Colleges of } \\
\text { technical } \\
\text { and further } \\
\text { education } \\
\text { (D4) }\end{array}$ & - Schools (D6) \\
\hline
\end{tabular}

\section{The Theory of Academic Library Strategic and Cultural Engagement}

The integrated substantive theory and model of academic library strategic and cultural engagement is presented here. The model (see figure 1) shows the relationships (arrows) between the strategies (boxes) and explains how (text) the library engages with its stakeholders. ${ }^{60}$

The model illustrates the process that begins with the agency of the library director who notes the problems caused by the diversity of stakeholder needs and, with the library's leadership group, responds by recognizing the need to know the stakeholders and their needs. This problem is solved by the strategy of developing a strategic engagement framework for each stakeholder group. The framework accounts for differences in stakeholder priority, language, and communication styles. The library director also intentionally and strategically nurtures an engaged organizational culture. This means all library staff are focused on customer service and collaborating with other university units, can respond to stakeholder needs in an agile way, and can promote the library and its services. The library also requires a team culture that is encouraged by a less hierarchical organizational structure and reporting structures that allow teams to make their own decisions without referring service problems to managers.

The double-headed arrow in the model demonstrates the mutual dependency of the strategy of an engagement framework and an engaged organizational culture that is customer focused and empowers staff and teams to make service decisions. In short, an engagement strategy cannot thrive in the absence of an engaged organizational culture, and an engaged culture does not have momentum without strategy. The intertwined strategy and culture are then enacted through various mechanisms with the internal and external stakeholders.

\section{Discussion}

\section{Variations between University Contexts}

A discussion of the differences in stakeholder engagement between university contexts requires some caution due to the small size of the sample and the exploratory nature of the 
FIGURE 1

The Model of Academic Library Strategic and Cultural Engagement with Academic Library Stakeholders

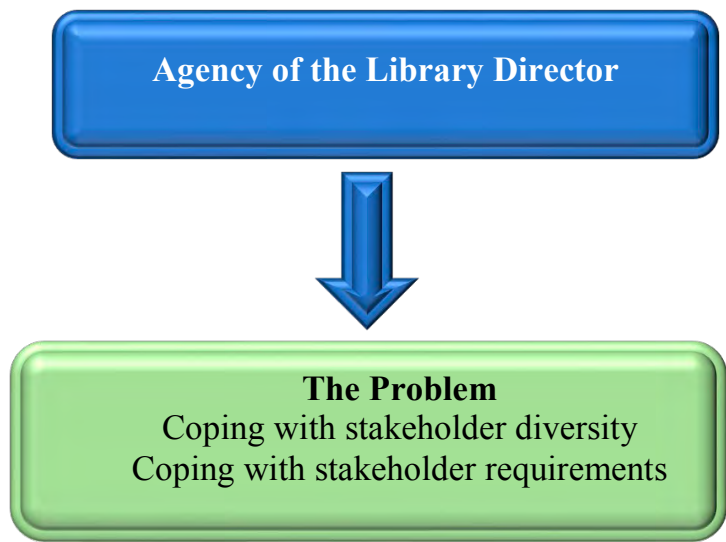

Strategy of Stakeholder Engagement Framework

Different strategies for different stakeholders

Whole organization approach

Using stakeholder language

Internal Engagement Mechanisms

Formal mechanisms University executive Informal networking with faculties

Formal partnerships and projects

Liaison with academic staff

Supporting researchers

Engaging and retaining students

Quantitative and qualitative feedback

Responding to feedback

Promotional work

\section{Strategy of Engaged Culture}

Customer-focused

Collaborating with stakeholders

Responsive to stakeholders

Promoting the library

Egalitarian team culture

Open communication with library staff

Collaborative staff culture

Working toward a common vision

\section{External Engagement Mechanisms}

Social and traditional media promotion with local community

Personal liaison for monetary and special collections

Collaborating with communities of practice

Networking with library sector

Working with schools and feeder institutions 
research. However, a major difference between American and Australian participants is that both American library directors nominated the State, its government and its citizens, as their major stakeholder, while the Australian participants appeared see the university as a business, with their emphasis upon promoting the library and the university to the wider community. This approach possibly derives from government funding cuts to Australian universities in recent years, leading to a focus on creating new business models and seeking funding from external sources. The new approach is required in Australia because, as D11 remarked, philanthropy is not a common tradition in Australia as it is in North America.

The elite and technology university library directors were most interested in developing a holistic approach or framework for engagement. Although all university types regarded customer focus and engagement as important, the elite university participants did not mention flexibility or responsiveness.

While research support was important for all university types, the smaller Australian regional libraries struggled to service a smaller number of researchers among a more diverse student population. Indeed, the regional libraries appeared to require more engagement activity with struggling first-year and Technical and Further Education (TAFE) students than the larger metropolitan libraries. While the larger institutions employed more staff for research support, the staff in regional libraries were required to undertake extra training to increase their research support capabilities.

The libraries in larger institutions appear to have the resource capacity to employ marketing or fundraising staff. In contrast, the regional libraries seem to engage with stakeholders at an individual level. Engagement with external stakeholders shows that elite universities tend to benefit financially from the goodwill of high-profile supporters and alumni, while research universities in regional areas rely upon the donations of special collections.

\section{Applying the Theory of Academic Library Strategic and Cultural Engagement} Many of the findings of this study reflect Lynda Bourne's maturity model of stakeholder relationship management. ${ }^{61}$ This model derives from project management research and provides a four-step guideline that includes identifying, prioritizing, mapping the stakeholders and then implementing various communication strategies. Bourne ${ }^{62}$ also argues that the attitude of stakeholders toward an organization is shaped by several factors including the culture of the organization, whether stakeholders' involvement is personally advantageous or beneficial to the organization, and the depth of financial or emotional investment. The theory of academic library strategic and cultural engagement differs by offering a theory that is specific to academic libraries. It also finds the specific elements of the culture including a customer focus, willingness to collaborate with other units and individuals, responsiveness to stakeholder needs, and promotion of services. The theory also emphasizes the empowerment of staff to engage with stakeholders and to make service decisions through teamwork.

The findings of this study also reflect the literature of Denise Koufogiannakis, ${ }^{63}$ as well as that of Peter Hernon, Robert Dugan, and Joseph Matthews, ${ }^{64}$ concerning evidence-based library and information practice (EBLIP). Hernon, Dugan, and Matthews state that EBLIP includes the following steps: asking a relevant question and then "gathering evidence; appraising the validity, reliability, and applicability of that evidence; applying the evidence to a decision; and evaluating the impact of the decision." ${ }^{65}$ However, the findings of this research emphasize the need for the library director and senior library management to expend more effort in developing a holistic framework for engagement and an engaged culture before beginning EBLIP. 
The competing values framework (CVF) of Kim Cameron and Robert Quinn ${ }^{66}$ and the research of other authors ${ }^{67}$ state that culture impacts strategy. This research extends this further by finding an interdependent nature of the relationship between strategy and culture. The constant engagement with stakeholders helps the library to refine and change services according to stakeholder feedback, and it enables staff to develop their engagement skills. It also encourages positive attitudes from stakeholders toward the library when feedback has been acted upon and when collaborations have been successful.

This research also adds to the ethnographic research of Otero-Boisvert ${ }^{68}$ that finds the library director's engagement with university administrators is most successful when persisting in advocacy for new projects over several years and managing well the relationships associated with projects. However, this study is significantly different because it focuses upon the library director's agency in ensuring that the library is engaging holistically with its entire range of stakeholders. To support this holistic engagement strategy, staff recruitment criteria and role descriptions will emphasize attitudes and personal attributes that reflect the engagement culture.

\section{Significance and Limitations of This Theory}

A major implication of this theory of strategic and cultural engagement is that it will assist the library to attain the collaborative support and commitment of stakeholders through their increased involvement with the library's services and activities. ${ }^{69}$ This is important for the university because collaborative partnerships reduce the possibility of failure, thus encouraging more creativity and innovation. ${ }^{70}$

Two main factors hampered the research process. First, while researching possible participants, many were ineligible due to their short time of incumbency in the position. This was particularly the case in the regional university sector, where it was difficult to find participants who met the criteria or were willing to take part in the research. A second regional participant (D12) was secured only during the theoretical sampling stage. To overcome any perception of lack of credibility for the data from regional university libraries, D12 was also interviewed in the final interview stage to check that the theory resonated. The second limitation is that the research does not examine the experiences and perceptions of other library staff members, and it does not explore the impact of the library on research or student outcomes. Further research is suggested to test the effect of the library upon its various stakeholders and the regional university library context.

\section{Conclusion}

This study finds that, to understand the requirements of the academic library's stakeholders and the efficacy of the library in meeting those needs, the library director develops a framework for engagement and combines it with a customer-focused, collaborative, responsive, and selfpromoting organizational culture. The culture also involves an egalitarian and team-based approach to decision making. The library then enacts the engagement strategy through mechanisms that involve library staff at all levels and are tailored to the needs and communication style of each stakeholder group. This research advances the literature about stakeholder engagement by reinforcing the importance of organizational culture. It provides an original contribution to library and information science literature by providing an understanding of the role of the library director in leading engagement strategy and culture. This research also offers a unique insight into the challenges various types of university libraries face in engaging with their stakeholders. 


\section{APPENDIX \\ Main interview question}

1. How do you maintain the relevance of your library to your stakeholders and extended community at the present time?

\section{Related interview questions}

1. Who are the stakeholders in your library at the present time?

2. What do you perceive to be the challenges facing your library at the present time?

3. How do you discover the challenges that affect your library?

4. How do you deal with these challenges?

5. How do you know that you and your staff are dealing with these challenges adequately?

6. Can you think of anything else that helps the library to achieve relevance to its stakeholders?

\section{Theoretical sampling questions}

1. How did you make the decisions about your library restructure?

2. Are there any factors that indicate success in maintaining the library's relevance to the university?

\section{Notes}

1. Daniel Kindström, Christian Kowalkowski, and Erik Sandberg, “Enabling Service Innovation: A Dynamic Capabilities Approach," Journal of Business Research 66, no. 8 (Aug. 2013): 1063-73; The Handbook of Service Innovation, eds. Renu Agarwal, Willem Selen, Göran Roos, and Roy Green (London: Springer, 2015).

2. Reflecting on the Future of Academic and Public Libraries, eds. Peter Hernon and Joseph R. Matthews (Chicago: ALA Editions, 2013); Shea-Tinn Yeh and Zhiping Walter, "Determinants of Service Innovation in Academic Libraries through the Lens of Disruptive Innovation," College E Research Libraries 77, no. 6 (Nov. 2016): 795-804.

3. Julie Garrison, Marianne Ryan, and Kathleen DeLong, "Moving Up: Positioning for Director Roles in Academic Libraries," in The Associate University Librarian Handbook: A Resource Guide, ed. Bradford Lee Eden (Lanham, MD: Scarecrow Press, 2012): 137-59.

4. Lynda Bourne, Stakeholder Relationship Management: A Maturity Model for Organisational Implementation (Abingdon, UK: Routledge, 2016), 93.

5. Ibid., 30.

6. Edgar H. Schein, Organizational Culture and Leadership, 4th ed. (Hoboken, NJ: Jossey-Bass, 2010).

7. Garrison, Ryan, and DeLong, "Moving Up," 137-59.

8. Rebecca Martin, "Recruiting a Library Leader for the 21st Century," in The Academic Library Director: Reflections on a Position in Transition, ed. F. D'Andraia (New York: Routledge, 2013).

9. Bourne, Stakeholder Relationship Management.

10. Fiona Harland, "How the University Librarian Ensures the Relevance of the Library to Stakeholders: A Constructivist Grounded Theory" (PhD diss., QUT, 2017), available online at https://eprints.qut.edu.au/106745/ [accessed 20 May 2017].

11. Fiona Harland, Glenn Stewart, and Christine Bruce, "Ensuring the Academic Library's Relevance to Stakeholders: The Role of the Library Director," Journal of Academic Librarianship 43, no. 5 (2017): 397-408, doi:10.1016/j. acalib.2017.06.009.

12. Kathy Charmaz, Constructing Grounded Theory, 2nd ed. (Los Angeles: SAGE, 2014), 230.

13. A. Parasuraman, "Assessing and Improving Service Performance for Maximum Impact: Insights from a Two-Decade-Long Research Journey," Performance Measurement and Metrics 5, no. 2 (2004): 45-52.

14. Rachel Esson, Alison Stevenson, Maureen Gildea, and Sue Roberts, "Library Services for the Future: Engaging with Our Customers to Determine Wants and Needs," Library Management 33, no. 8/9 (2012): 469-78, doi:10.1108/01435121211279830. 
15. Ben Wynne, Simon Dixon, Neil Donohue, and Ian Rowlands, "Changing the Library Brand: A Case Study," New Review of Academic Librarianship 22, no. 2/3 (2016): 1-13, doi:10.1080/13614533.2016.1156000.

16. Kayo Denda, “Developing Interview Skills and Visual Literacy: A New Model of Engagement for Academic Libraries," portal: Libraries and the Academy 15, no. 2 (2015): 299-314.

17. Kayo Denda and Jennifer Hunter, "Building 21st Century Skills and Creating Communities: A Team-Based Engagement Framework for Student Employment in Academic Libraries," Journal of Library Administration 56, no. 3 (2016): 251-65, doi:10.1080/01930826.2015.1121662.

18. Mark Robertson, "Perceptions of Canadian Provosts on the Institutional Role of Academic Libraries," College E Research Libraries 76, no. 4 (2015): 490-511. doi:10.5860/crl.76.4.490.

19. Roisin Gwyer, "Identifying and Exploring Future Trends Impacting on Academic Libraries: A Mixed Methodology Using Journal Content Analysis, Focus Groups, and Trend Reports," New Review of Academic Librarianship 21, no. 3 (2015): 269-85, doi:10.1080/13614533.2015.1026452.

20. L. Johnson, S. Adams Becker, V. Estrada, and A. Freeman, NMC Horizon Report: 2015 Library Edition (Austin, TX: The New Media Consortium, 2015), available online at http://cdn.nmc.org/media/2015-nmc-horizon-reportlibrary-EN.pdf [accessed 26 May 2017].

21. Zelda Chatten and Sarah Roughley, "Developing Social Media to Engage and Connect at the University of Liverpool Library," New Review of Academic Librarianship 22, no. 2/3 (2016): 1-8, doi:10.1080/13614533.2016.1152 985.

22. Geraldine Delaney and Jessica Bates, "Envisioning the Academic Library: A Reflection on Roles, Relevancy and Relationships," New Review of Academic Librarianship 21, no. 1 (2015): 30-51, doi:10.1080/13614533.2014.911194.

23. Laura Saunders, "Academic Libraries' Strategic Plans: Top Trends and Under-Recognized Areas," Journal of Academic Librarianship 41, no. 3 (2015): 285-91, doi:10.1016/j.acalib.2015.03.011.

24. Matthew P. Long and Roger C. Schonfeld, "Ithaka S+R US Library Survey 2013" (New York: Ithaka, 2014), available online at https://scholar.google.com.au/scholar?hl=en\&q=Long+Schonfield+Ithaka\&btnG=\& as_sdt $=1 \% 2 C 5 \&$ as_sdtp= [accessed 30 May 2017].

25. Yvonne Nalani Meulemans and Allison Carr, "Not at Your Service: Building Genuine Faculty-Librarian Partnerships," Reference Services Review 41, no. 1 (2013): 80-90, doi:10.1108/00907321311300893.

26. Jared Hoppenfeld and Elizabeth Malafi, "Engaging with Entrepreneurs in Academic and Public Libraries," Reference Services Review 43, no. 3 (2015): 379-99, doi:10.1108/RSR-02-2015-0011.

27. Belinda Tiffen and Ashley England, "Engaging with Clients and Personalising Services at UTS Library: Measuring the Value for Libraries and Their Clients," Australian Library Journal 60, no. 3 (2011): 237-47, doi:10.10 80/00049670.2011.10722620.

28. Steven D. Shapiro, "Engaging a Wider Community: The Academic Library as a Center for Creativity, Discovery and Collaboration," New Review of Academic Librarianship 22, no. 1 (2016): 24-42, doi:10.1080/13614533 .2015.1087412.

29. Finbar Galligan and Sharon Dyas-Correia, "Altmetrics: Rethinking the Way We Measure," Serials Review 39, no. 1 (2013): 56-61, doi:10.1016/j.serrev.2013.01.003.

30. Johnson et al., NMC Horizon Report.

31. Melissa Dennis, "Outreach Initiatives in Academic Libraries, 2009-2011," Reference Services Review 40, no. 3 (2012): 368-83, doi:10.1108/00907321211254643.

32. Saunders, "Academic Libraries' Strategic Plans," 285-91.

33. Shapiro, "Engaging a Wider Community," 24-42.

34. Maria Otero-Boisvert, "Funding the Academic Library: An Ethnographic Study" (PhD diss., QUT, 2015), available online at http://eprints.qut.edu.au/84749/ [accessed 14 June 2016].

35. Robertson, "Perceptions of Canadian Provosts on the Institutional Role of Academic Libraries," 490-511.

36. Linh Cuong Nguyen, "Establishing a Participatory Library Model: A Grounded Theory Study," Journal of Academic Librarianship 41, no. 4 (2015): 475-87, doi:10.1016/j.acalib.2015.03.018.

37. Ibid.

38. Kathy Charmaz, "Shifting the Grounds: Constructivist Grounded Theory Methods," in Developing Grounded Theory: The Second Generation, eds. Janice M. Morse, Phyllis Noerager Stern, Juliet Corbin, Barbara Bowers, Kathy Charmaz, and Adele E. Clarke (Walnut Creek, CA: Left Coast Press, 2009), 127-54.

39. Barney G. Glaser and Anselm G. Strauss, Discovery of Grounded Theory: Strategies for Qualitative Research (New York: Aldine, 1967), 32.

40. Kathy Charmaz, "Constructionism and the Grounded Theory Method," in Handbook of Constructionist Research, eds. J.A. Holstein and J.F. Gubrium (New York: Guilford Press, 2008), 397-412.

41. Charmaz, Constructing Grounded Theory.

42. Ibid. 
43. Ibid.

44. Karen Henwood and Nick Pidgeon, "Grounded Theory in Psychological Research," in Qualitative Research in Psychology: Expanding Perspectives in Methodology and Design, eds. Paul M. Camic, Jean E. Rhodes, and Lucy Yardley (Washington, DC: American Psychological Association, 2003), 131-55.

45. Charmaz, Constructing Grounded Theory.

46. Simon Marginson and Marijk van der Wende, "The New Global Landscape of Nations and Institutions," in Higher Education to 2030 (Paris: OECD Publishing, 2009), 17-62.

47. Simon Marginson, "Nation-Building Universities in a Global Environment: The Case of Australia," Higher Education 43, no. 3 (2002): 409-28, doi:10.1023/A:1014691304966.

48. Harland, "How the University Librarian Ensures the Relevance of the Library to Stakeholders," 105.

49. Charmaz, Constructing Grounded Theory, 64.

50. Kathy Charmaz, "Grounded Theory: Objectivist and Constructivist Methods," in Handbook of Qualitative Research, 2nd ed., eds. Norman K. Denzin and Yvonna S. Lincoln (Thousand Oaks, CA: SAGE, 2000).

51. Glenn A. Bowen, "Naturalistic Inquiry and the Saturation Concept: A Research Note," Qualitative Research 8, no. 1 (2008): 137-52, doi:10.1177/1468794107085301; Mark Mason, "Sample Size and Saturation in PhD Studies Using Qualitative Interviews," Forum: Qualitative Social Research 11, no. 3 (2010), available online at www.qualitative-research.net/index.php/fqs/article/view/1428/3028 [accessed 17 August 2015]; Greg Guest, Arwen Bunce, and Laura Johnson, "How Many Interviews are Enough? An Experiment with Data Saturation and Variability," Field Methods 18, no. 1 (2006): 59-82, doi:10.1177/1525822x05279903.

52. Charmaz, Constructing Grounded Theory, 26.

53. Barney G. Glaser and Anselm G. Strauss, Discovery of Grounded Theory: Strategies for Qualitative Research (New York: Aldine, 1967), 106.

54. Charmaz, Constructing Grounded Theory, 140.

55. Harland, "How the University Librarian Ensures the Relevance of the Library to Stakeholders," 129; Charmaz, Constructing Grounded Theory, 150.

56. Charmaz, Constructing Grounded Theory, 341.

57. Charmaz, Constructing Grounded Theory, 337.

58. David A. Whetten, “What Constitutes a Theoretical Contribution?" Academy of Management Review 14, no. 4 (1989): 490-95.

59. Ibid.

60. Ibid.

61. Bourne, Stakeholder Relationship Management.

62. Ibid., 94.

63. Denise Koufogiannakis, "Determinants of Evidence Use in Academic Librarian Decision Making," College E Research Libraries 77, no. 1 (Jan. 2015): 100-14, doi:10.5860/crl.76.1.100.

64. Peter Hernon, Robert E. Dugan, and Joseph R. Matthews, Getting Started with Evaluation (Chicago: American Library Association, 2014).

65. Ibid., 22.

66. Kim S. Cameron and Robert E. Quinn, Diagnosing and Changing Organizational Culture (San Francisco: Jossey-Bass, 2011).

67. A.A. van der Maas, "Strategy Implementation in a Small Island Community: An Integrative Framework" (PhD diss., Erasmus University, 2008), available online at http://repub.eur.nl/pub/12278/ [accessed 11 July 2016]; S.A.A. Ahmadi, Y. Salamzadeh, M. Daraei, and J. Akbari, "Relationship between Organizational Culture and Strategy Implementation: Typologies and Dimensions," Global Business and Management Research 4, no. 3/4 (2012): 286-99.

68. Otero-Boisvert, "Funding the Academic Library: An Ethnographic Study."

69. Bourne, Stakeholder Relationship Management.

70. Mark Bieraugel, "Managing Library Innovation Using the Lean Startup Method," Library Management 36, no. 4/5 (2015): 351-61. 